\title{
PENGENALAN STABILISASI TANAH DENGAN JET GROUTING
}

\author{
Indrastono Dwi Atmanto \\ Email : indrastono.dwiatmanto@gmail.com
}

\begin{abstract}
Due to restriction of land availability it is frequently we have to build constructions on soft or low bearing capacity soils, so that soil stabilization must be applied in order to increase its properties. There are many techniques of soil stabilization, where its applicability depends on many factors regarding appropriate engineering judgement. This paper presents the soil stabilization method by jet grouting, including its theory and practice.

Keywords : Soil Stabilization, Jet Grouting, Bearing Capacity.
\end{abstract}

\section{Pendahuluan}

Proyek-proyek Teknik Sipil seringkali dirancang untuk dibangun di atas lahan yang terkendala oleh bangunan-bangunan eksisting, areal tanah lunak atau secara teknis tanah dasar bermasalah. Pada beberapa kasus, diperlukan perbaikan tanah dasar lunak guna mendukung beban bangunan di atasnya. Perbaikan tanah dapat meningkatkan sifat-sifat fisik maupun mekanik, utamanya daya dukung dan modulus elastisitas serta memperkecil permeabilitasnya. Metoda jet grouting merupakan salah satu sistem terpilih untuk maksud tersebut. Pemakaian jet grouting untuk stabilisasi tanah berawal dari Inggris dan Jepang hingga meluas ke seluruh dunia.

\section{Teori Jet Grouting}

Jet grouting (Camberfort, 1969) merupakan proses khusus yang menghasilkan pencampuran tanah dan semen di tempat (in situ). Setelah tercapai kedalaman pemboran yang direncanakan maka batang bor diputar dan diangkat ke permukaan tanah sesuai laju rencana, sambil menyuntikkan bahan injeksi pasta semen dengan tekanan tinggi sehingga terbentuk kolom semen-tanah. Apabila dirancang dalam kon-figurasi teknis yang tepat maka kolom dapat dikonstruksi untuk menyediakan penanganan efektif dari massa tanah. Keuntungan metoda jet grouting meliputi : kuat tekan tanah yang lebih tinggi dibanding metoda perbaikan tanah yang lain; perbaikan tanah dengan mutu yang lebih merata dan seragam; kemampuan untuk perbaikan tanah di daerah terpencil serta kuantitas definitif maupun penjadualan pekerjaan secara sistematis. Jet grouting merupakan proses pencampuran tanah dengan bahan stabilisasi (umumnya semen Portland) yang disuntikkan dengan tekanan sangat tinggi (300-600 bar) melalui nozzle berdia-meter kecil. Kecepatan penetrasi yang tinggi me-mampukan proses jet grouting merusak susunan matriks butiran tanah dan menghasilkan pencam-puran pasta semen dengan butiran tanah membentuk beton-tanah (soilcrete) di tempat. Hasilnya adalah elemen struktural kontinyu sesuai dengan karak-teristik rencana. Jet grouting dapat diaplikasikan da-lam rentang sifat yang luas mulai tanah non kohesif, tanah granuler bergradasi buruk hingga lempung plastis kohesif.Tek-

\footnotetext{
*) Staf Pengajar Jurusan Teknik Sipil Fakultas Teknik Universitas Diponeogor
}

nik jet grouting merupakan suatu alternatif pilihan di antara berbagai metoda injeksi tanah.

\section{Metoda Pelaksanaan Soilcrete}

Peralatan yang digunakan untuk jet grouting dapat dilihat pada gambar 1, sedangkan metoda pelaksanaannya terdiri dari tiga fase (gambar 2) :

Fase A : Pemboran tanah sampai kedalaman rencana

Fase B : Penghancuran matriks tanah dengan penyemprotan air atau suspensi semen dengan atau tanpa tambahan udara dengan pompa bertekanan tinggi 300 - 600 bar.

Fase $\mathrm{C}$ : Pencampuran butiran tanah dengan pasta semen dan pembuatan massa sementanah homogen.

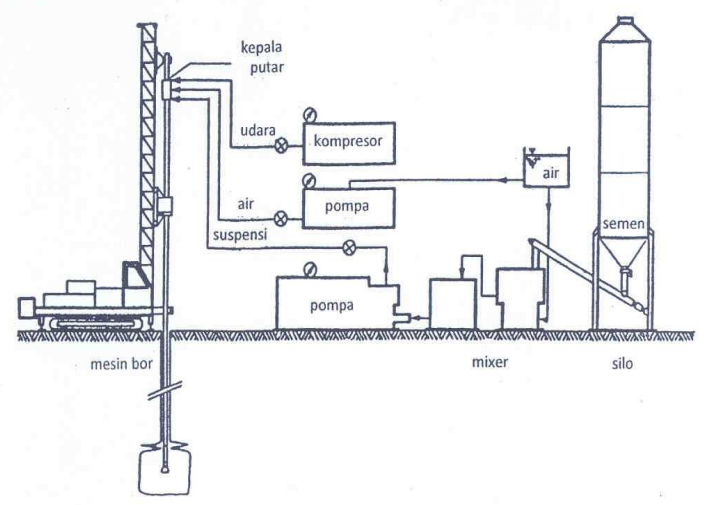

Gambar 1 Peralatan Jet Grouting (Rizkallah 1989)

Ditinjau dari viskositas bahan injeksi dapat dibedakan 3 macam teknik jet grouting (Keller-Grundbau, 2013) :

1. Soilcrete $\mathrm{S}$ (Single)

Dalam metoda ini digunakan pipa injeksi tunggal. Penyemprotan dengan suspensi bertekanan tinggi. Soilcrete $\mathrm{S}$ merupakan sistem paling sederhana yang disukai oleh para kontraktor untuk proyekproyek bangunan yang sensitif. Suspensi semen disuntikkan dengan tekanan tinggi melalui nozzle kecil sehingga bercampur secara homogen dengan butiran tanah. Metoda ini mampu menghasilkan elemen tanah-semen paling homogin dengan kekuatan maksimal dan sisa material minimum. 
2. Soilcrete D (Double)

Digunakan dua pipa injeksi untuk suspensi semen dan udara. Suspensi semen diinjeksikan dengan dengan tekanan tinggi dibantu kerucut udara termampatkan yang membantu proses injeksi. Udara dapat mereduksi kehilangan gesekan yang memampukan suspensi semen mengalir lebih lanjut dari titik injeksi sehingga menghasilkan diameter kolom lebih besar. Namun keberadaan udara mereduksi kekuatan kolom dibanding metoda injeksi tunggal dan mengakibatkan lebih banyak spoil return (perusakan kembali susunan matriks tanah).

\section{Soilcrete T (Triple)}

Soilcrete $T$ menggunakan tiga pipa terpisah masing-masing untuk air, udara dan suspensi semen. Perusakan matriks butiran tanah oleh semprotan air dan udara bertekanan tinggi, sedangkan suspensi semen disuntikkan secara terpisah. Berbeda dengan soilcrete $S$ maupun $\mathrm{D}$, di sini air disuntikkan dengan tekanan tinggi dan dibantu dengan kerucut udara mampat. Cara ini menghasilkan suatu efek pengangkatan udara yang mengevakuasi tanah sesuai diameter kolom yang direncanakan. Massa injeksi disuntikkan pada tekanan lebih rendah melalui nozzle terpisah di bawah air dan nozzle udara untuk mengisi poripori akibat proses pengangkatan udara. Sejatinya soilcrete $T$ merupakan suatu penggantian tanah (soil replacement), bukan metoda pencampuran di tempat. Metoda ini menghasilkan lebih banyak spoil return dibanding soilcrete $S$ maupun $D$.

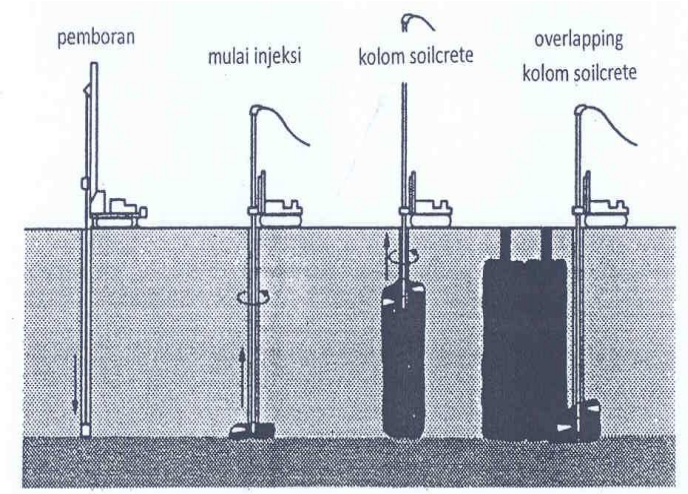

\section{Gambar 2 Metoda Pelaksanaan Jet Grouting (Berg, 1986)}

\section{Kriteria Pemakaian Jet Grouting}

Jet grouting merupakan metoda perbaikan tanah yang bebas getaran, kebisingan dan ramah lingkungan. Rentang pemakaian jet grouting terbentang mulai dari tanah berbutir halus hingga kasar (gambar 3), dan dapat diaplikasikan pada berbagai kondisi berikut:

1. Metoda ini dapat diterapkan pada hampir semua jenis tanah.

2. Kenaikan fraksi butiran halus mengakibatkan pula bertambahnya kebutuhan enerji dan material.

3. Pada tanah organik murni dengan air tanah agresif dapat timbul permasalahan kualitas soil crete.

4. Pipa injeksi dapat diperpanjang sesuai kebutuhan sehingga massa injeksi mampu mencapai kedalaman rencana yang ditentukan oleh kapasitas mesin bor.

5. Limbah jet grouting bersifat ramah lingkungan, dalam waktu 24 jam sudah mengeras sehingga mudah diangkut ke tempat pembuangan.

6. Dengan parameter yang sama maka pada tanah lempung dan lanau kelempungan akan dihasilkan diameter soilcrete yang lebih kecil dibanding pada tanah pasir.

7. Dalam tanah kerikil kasar, hasil jet grouting akan setara dengan metoda injeksi semen.

8. Harga produksi jet grouting tergantung dari kepadatan dan kedalaman injeksi, pada kondisi lapangan yang sulit akan membengkak juga harganya.

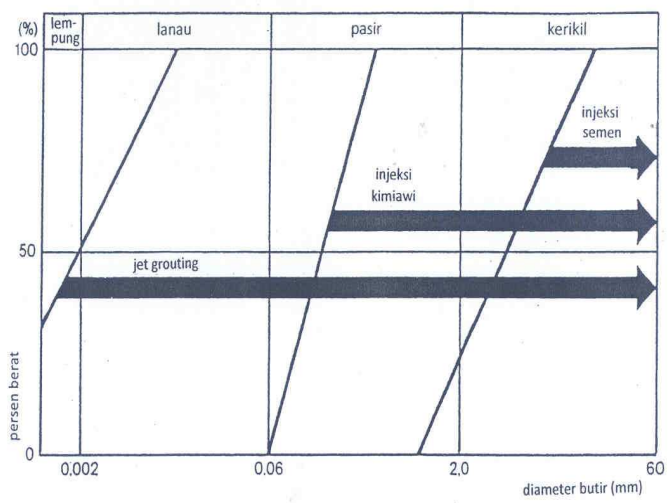

Gambar 3 Rentang pemakaian injeksi semen, kimiawi dan Jet Grouting

(Rizkallah, 1989)

\section{Karakteristik Soilcrete}

Radius penetrasi jet grouting atau diameter kolom soilcrete sangat dipengaruhi jenis tanah, khususnya kepadatan lapangan dan konsistensi. Dengan pemilihan metoda parameter pelaksanaan yang tepat (tekanan pompa, diameter dan jumlah packer, kecepatan putar dan tarik pipa injeksi) dapat dihasilkan diameter kolom sesuai rencana, umumnya berkisar 0,6 - 2,0 m. Kekuatan soilcrete dipengaruhi oleh kadar semen, komposisi tanah dan kadar air. Nilai Kekuatan maksimum stabilisasi tanah jet grouting dapat diselidiki dari hasil uji Unconfined Compressive Strength (Rizkallah, 1989) :

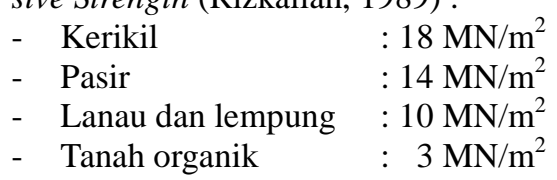

Sedangkan berat volume soilcrete berkisar $16-20$ $\mathrm{kN} / \mathrm{m}^{3}$. Perilaku permeabilitas soilcrete menyerupai massa beton pada umumnya, dengan koefisisen permeabilitas antara $10^{-7}$ hingga $10^{-9} \mathrm{~m} /$ detik. Akibat fraksi halus dalam tanah atau penambahan bentonit untuk suspensi maka nilai permeabilitasnya semakin 
menurun. Untuk keperluan praktis dapat dianggap bahwa soilcrete bersifat kedap air. Ditinjau dari metoda pelaksanaannya, soilcrete merupakan keberhasilan aplikasi teknologi beton sejak lebih dari 100 tahun yang lalu. Fungsi agregat dan pasir dalam soilcrete digantikan oleh butiran tanah alami, sehingga analisis perilaku jangka panjang dapat diadopsi dari pengalaman teknologi beton. Karakteristik soilcrete tersaji dalam tabel 1.

Tabel 1 Karakteristik soilcrete (Rizkallah, 1989)

\begin{tabular}{|l|c|c|}
\hline \multicolumn{1}{|c|}{ Jenis Tanah } & $\begin{array}{c}\text { Diameter } \\
\text { Kolom (inch) }\end{array}$ & $\begin{array}{c}\text { Kuat Tekan } \\
\text { (psi) }\end{array}$ \\
\hline \multicolumn{3}{|c|}{ So i l c r e te S } \\
\hline Pasir \& kerikil & $2-4$ & $1000-3000$ \\
Lempung & $2-3$ & $250-1000$ \\
\hline \multicolumn{3}{|c|}{ So i l c re te D } \\
\hline Pasir \& kerikil & $3-6$ & $500-2000$ \\
Lempung & $3-5$ & $150-1000$ \\
\hline \multicolumn{3}{|c|}{ o i l c r e te T } \\
\hline Pasir \& kerikil & $5-8$ & $500-2000$ \\
Lempung & $3-6$ & $150-1000$ \\
\hline
\end{tabular}

\section{Geometri Soilcrete}

Bentuk geometri soilcrete tergantung dari susunan dan gerakan packer. Penetrasi jet grouting akan membentuk silinder berdiameter beberapa sentimeter. Dengan gerakan longitudinal packer akan menghasilkan suatu pias satu sisi; sedangkan putaran dan gerakan pipa injeksi secara simultan dan serasi akan menghasilkan kolom soilcrete. Akibat putaran dan gerakan packer yang tidak harmonis, maka akan dihasilkan kolom soilcrete yang kurang masif. Melalui anyaman beberapa elemen pias dapat dihasilkan dinding injeksi, underpinning dan lapis injeksi kedap air.

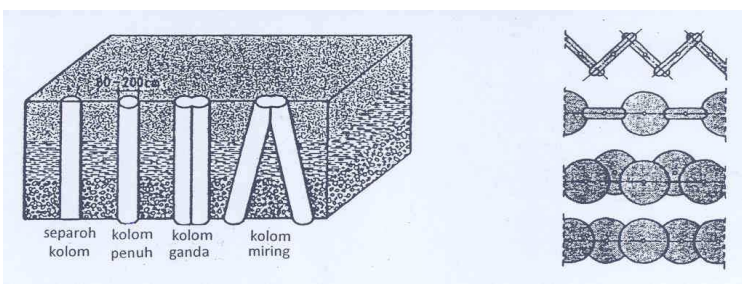

Gambar 4 Geometri soilcrete (Müllerkirchenbauer, 1992)

\section{Cakupan Pemakaian}

Jet grouting dapat digunakan secara luas untuk berbagai pekerjaan stabilisasi tanah seperti perkuatan pondasi, lapis kedap air maupun masalah aliran rembesan (Keller-Grundbau, 2013).

Pemakaian jet grouting untuk stabilisasi tanah meliputi :

1. Underpinning : perkuatan pondasi, dinding penahan tanah, stabilitas lereng

2. Perlindungan terowongan pada tanah lunak/lepas di bawah bangunan dan mencegah rembesan pada waktu penggalian terowongan.
3. Peningkatan kapasitas dukung pondasi.

Sedangkan untuk konstruksi kedap air, jet grouting dapat digunakan pada pekerjaan :

1. Dinding dan lapisan dasar kedap air galian tanah.

2. Dinding cut-off pada bendungan dan talang air.

3. Lapis kedap air pada barisan tiang, turap dan dinding diafragma.

4. Dasar kedap air pada deponi sampah.

\section{Kesimpulan dan Saran}

Metoda jet grouting merupakan salah satu metoda stabilisasi tanah yang handal dan dapat diaplikasikan pada semua jenis tanah. Selain metoda pelaksanaannya sederhana, jet grouting bersifat ramah lingkungan dan cakupan pemakaiannya sangat luas. Perbaikan sifat-sifat fisik, mekanik, peningkatan daya dukung dan pengurangan penurunan dapat dicapai dengan jet grouting. Inovasi teknologi peralatan, material maupun metoda pelaksanaan jet grouting perlu terus dilakukan untuk memperoleh hasil stabilisasi tanah yang semakin baik.

\section{Daftar Pustaka}

1. Berg, J; Samol, H, Soilcrete - ein Bodenverbesserungsverfahren in Grund -und Wasserbau, Wasser und Boden, 1986

2. Camberfort, H, Bodeninjektionstechnik, Bauverlag Wiesbaden, 1969

3. Keller-Grundbau, Soilcrete, Firmenprospektus, 2013

4. Kirchenbauer, Müller, Dammbau und Injektionstechnik, IGBE Hannover, 1992

5. Rizkallah, V, Baugrundinjektionen mit hohen Drücken, IGBE Hannover, 1989 
